\title{
CONTROVERSY BETWEEN THE TAX COURT AND COURTS OF APPEALS: IS THE TAX COURT BOUND BY THE PRECEDENT OF ITS REVIEWING COURT?
}

The extent to which the Tax Court must follow the decisions of a particular circuit court of appeals when adjudicating the rights of a taxpayer whose appeal would lie to that circuit ${ }^{1}$ has recently occasioned some controversy. ${ }^{2}$ In Arthur L. Lawrence, ${ }^{3}$ the Tax Court enunciated the principle that when confronted by an issue on which the taxpayer's circuit had previously ruled, it would re-examine the question in the light of this opinion; but that unless persuaded of the correctness of this determination, it would adhere to a contrary position. In justification of this seeming obduracy, the Tax Court observed that Congress, in establishing the old Board of Tax Appeals, ${ }^{4}$ intended it to provide a

\footnotetext{
${ }^{3}$ The United States Courts of Appeals have exclusive jurisdiction to review the decisions of the Tax Court. INT. REv. CODE of 1954, § 7482(a).

2 The initial shot in this controversy was fired by the Court of Appeals for the Sixth Circuit when it said that the Tax Court was legally bound to follow decisions of the reviewing circuit. Stacey Manufacturing Co. v. Commissioner, 237 F.2d 605 (6th Cir. 1956). The Tax Court countered in Arthur L. Lawrence, 27 T.C. No. 82 (Jan. 25, 1957), by adding to its opinion in that case the proposition that even if its decision was not distinguishable from one of the reviewing circuit, it was not bound to adhere to the decision of the circuit. The Court of Appeals for the Seventh Circuit was the next to join the fray. Sullivan v. Commissioner, 24I F.2d 46 (7th Cir. 1957). Here the court reproached the Tax Court for not following an earlier Seventh Circuit decision, Doyle v. Commissioner, 234 F.2d 788 (7th Cir. 1956), even though Doyle was decided by the Seventh Circuit some four months after the Tax Court's decision in Sullivan.

Although this is the first time that this particular controversy has arisen, it has always been assumed that the Tax Court is not bound by the precedent of a circuit to which the petitioner can not take his appeal as a matter of right. See, Max Putnam, P-H 1954 T.C. Mem. Dec. If 54,140, where the Tax Court refused to follow Pollack v. Commissioner, 209 F. 2d 57 (3rd Cir. 1953); Edwards v. Allen, 216 F. 2d 794 (5th Cir. 1954); and Cudlip v. Commissioner, 220 F.2d 565 (6th Cir. 1954). The Tax Court was later affirmed by the Supreme Court. Putnam v. Commissioner, 352 U.S. 82 (1956). See also, Millar Brainard, 7 T.C. 1180 (1946), where the Tax Court, adjudicating the rights of a petitioner from the Sixth Circuit, refused to follow a decision from the Eighth Circuit which had reversed the Tax Court's original holding. Zinnmerman Steel Co. v. Commissioner, r30 F.2d rori (8th Cir. 1942), reversing, Zimmerman Steel Co., 45 B.T.A. 1041 (1941).

${ }_{27} 7$ T.C. No. 82 (Jan. 25,1957 ).

'INT. REv. CODE of 1924, § 900 .
} 
uniform application of the federal tax laws ${ }^{5}$ throughout the country. ${ }^{6}$ This objective would be impossible of attainment, it was pointed out, if the Tax Court were constrained to honor the possibly conflicting decisions of the various circuits in different cases.

Other considerations also inclined the Tax Court to this position. A difficult problem would arise, for example, when there was uncertainty as to which circuit the appeal of a particular case might be taken. Equally troublesome would be the problem when the case determined the rights of taxpayers whose appeals lay to different circuits. ${ }^{7}$

The Sixth Circuit Court of Appeals, in Stacey Mfg. Co. v. Commissioner, ${ }^{7 \mathrm{a}}$ however, in a per curiam opinion, expressed a diametrically opposed view, pointedly noting that the Tax Court is "not lawfully privileged to disregard" the decision of a court of appeals in a case involving a taxpayer from that circuit. In support of this stand, the circuit court relied on its authority to affirm, reverse, or modify the decisions of the Tax Court on appeal. ${ }^{8}$ It concluded that the refusal of the Tax Court to be bound by the precedent of the circuit courts was tantamount to reversing them, a power that resides exclusively in the Supreme Court.

For some time after the Board of Tax Appeals was created to determine controversies over disputed tax deficiencies assessed by the

\footnotetext{
Among the references to legislative history which the Tax Court in Lawrence cited as authority for this proposition was 67 Cong. REc. $1136-37$ (1925), where the only mention of the intention to have the Tax Court uniformly apply the Statute was in a discussion on the floor of the House concerning whether the Board of Tax Appeals should hand down written findings of fact and law. There Mr. McLauglin of Michigan said that in order to have a uniform system of taxation throughout the country, it was necessary for the Board to put its decisions in writing. The court also cited 67 CoNG. REC. 3749 (1926), where Senator King of Utah said, in a debate over the number of judges necessary for the efficient operation of the Board, that the number of cases would be much reduced when the Board established a uniform application of the law.

- The Tax Court has jurisdiction to hear appeals from deficiency assessments by the Commissioner anywhere in the Country. INT. REv. CODE of $195+, \$ \S 7+42,7+45$.

${ }^{7}$ An example of this situation advanced by the court in Laqurence is that of a case involving the problem of whether a payment made by a corporation to its stockholders is a non-taxable return of capital or a taxable dividend, and the stockholders, who reside in different circuits which are in confiict over the issue, join in a suit in the Tax Court. See, e.g., Edwin L. Wiegand, 14 T.C. 136 (1950), reversed, Tourtelot v. Commissioner, 189 F. 2d 167 (7th Cir. 1951); affirmed by the Third Circuit in an unreported opinion, June 22, 1953; later reversed, Wiegand v. Commissioner, 194 F.2d 479 (3rd Cir. 1954).

${ }_{237}$ F.2d 605 (6th Cir. 1956).

INT. REv. CODE of $1954, \S 7482$ (a).
} 
Commissioner, the scope of the review to which this agency's ${ }^{9}$ decisions were subject was uncertain. ${ }^{10}$ Although Congress originally conferred this jurisdiction on the eleven circuit courts of appeals, ${ }^{11}$ the Supreme Court sharply limited the manner in which it could be exercised in Dobson v. Commissioner ${ }^{12}$ by restricting review to questions involving "clear-cut mistakes of law."13 Instead of creating the desired certainty and uniformity ${ }^{14}$ in the application of tax laws, however, the Dobson case had an opposite effect. Not only was there uncertainty as to the finality of Tax Court decisions, but, owing to the fact that the vast

${ }^{\circ}$ According to the statutory language, the Tax Court, as was the Board of Tax Appeals before it, is an administrative agency and not a court. INT. REv. CODE of 1924, $\S 900$ (now INT. ReV. CODE of $1954, \S 7441$ ). The Supreme Court has held this body to be an admiuistrative agency exercising quasi-judicial power. Old Colony Trust Co. v. Commissioner, 279 U.S. 716 (1928); Goldsmith v. Board of Tax Appeals, 270 U. S. 117 (1926). It has distinguished the Tax Court's administrative status from that of a court. Commissioner v. Osterlien Machine Co., 275 U.S. 220 (1927); Williamsport Wire and Rope Co. v. United States, 277 U.S. 551 (1928). The House at one time considered making the Tax Court into a court, 93 CoNG. REC. 8387 (1947), but the Senate rejected this plan, 94 Cong. REc. 8438 (1947). Dean Griswold, however, says that actually the Tax Court is in organization, tradition, and function a judicial body. Griswold, The Need for a Court of Tax Appeals, 57 HaRv. L. REv. 1153 (1944).

${ }_{10}$ By the time that the Board of Tax Appeals was established, the circuit courts were used to reviewing the tax cases from the district courts in the same manner that they reviewed all other cases, and they continued to exercise this type of review over the Board until Dobson v. Commissioner, 320 U.S. 489 (1943). Paul, Dobson v. Commissioner: The Strange Ways of Law and Fact, 57 HARv. L. REv. 753 (1944). See also, Williamsport Wire and Rope Cn. v. United States, 271 U. S. 551 (1928).

11 When the Board of Tax Appeals was intially established, Congress did not provide for any appeal from the Board, but when the revenue act was amended in 1926, Congress gave this right to the courts of appeals.

12320 U.S. 489 (1943).

${ }^{13}$ Prior to the Dobson case the Supreme Court had held that "mixed questions of law and fact" which had been decided by the Board of Tax Appeals were reviewable. Helvering v. Texas Penn-Oil Co., 300 U.S. 481 (1937); Bogardus v. Commissioner, 302 U.S. 34 (1937). In the Dobson case the question was whether Congress had intended to exclude the application of the tax benefit rule in cases where it had not expressly provided for its use by statute. It would be hard to imagine a question which seemed to be a more clear-cut question of law than that, but the Supreme Court said that it was not the type which could be reviewed.

${ }^{24}$ Although after the Dobson decision, the courts of appeals shied away from reversing the decisions of the Tax Court, because no pattern ever developed out of the decisions of the Supreme Court from which the courts of appeals could determine the scope of their reviewing power. Paul, supra note 10. And with the courts of appeals abdicating the field, only the Supreme Court was left to review the decisions of the Tax Court. 
majority of them were decided by a single judge ${ }^{15}$ rather than by the court as a whole, they were often hard to reconcile. ${ }^{10}$

Disturbed by this situation, as well as by a decision holding that the Administrative Procedure Act governed the manner in which the circuit courts could exercise their appellate jurisdiction over the Tax Court, ${ }^{17}$ Congress enacted clarifying legislation in $1948 .^{18}$ As incorporated into the 1954 Code, $^{19}$ it gives to the circuit courts the authority to review rulings of the Tax Court "in the same manner and to the same extent" that they can review decisions of the district courts in cases tried without a jury. ${ }^{20}$ This, the circuit courts urge, unmistakably compels Tax Court adherence to their precedents.

Although the Tax Court is nominally "an agency of the executive branch of the government," it acts and functions as a part of the judiciary. ${ }^{21}$ Furthermore, congressional action in 1948 would seem clearly to indicate legislative intent that its decisions be reviewable as such. This, however, would appear to be incompatible with the asserted congressional intent that the Tax Court be free to formulate a uniform con-

${ }^{28}$ The Tax Court judge sitting alone is actually a separate court rather than 'part of the whole court. He is not bound by the decisions of the other judges of the court except those which were decided by the court sitting en banc. More than two thirds of the cases decided by the Tax Court in the years immediately following Dobson were decided by a single judge. Griswold, supra note 9, at 1172 .

${ }_{10}$ The problems which were caused by the Dobson decision were almost satirically illustrated in John Kelley Co. v. Commissioner, 326 U.S. 521 (1946). There two cases heard at approximately the same time by different judges of the Tax Court involved very similar facts. The question in both cases was whether a particular security was a stock or a bond. The Tax Court judges reached opposite results, and when the cases reached the Supreme Court through different courts of appeals, the Supreme Court affirmed both Tax Court decisions on the basis of the Dobson rule.

${ }^{17}$ In Lincoln Electric Co. v. Commissioner, 162 F.2d 379 (6th Cir. 1947), the court stressed the fact that the Tax Court was an administrative agency and said that the Administrative Procedure Act was controlling when its decisions were reviewed by the courts. The court seemed to be trying to establish a rule with more certainty than the Dobson rule.

The Dobson and Lincoln Electric Co. cases were specifically mentioned on the floor of the House as reasons for-amending the statute which gave the power of review to the courts of appeals, and for wanting to change the status of the Tax Court from that of an agency to that of a court. 93 CONG. REC. $8385-83^{89}$ (1947).

${ }^{18}$ INT. REv. CODE of 1939, $\S 1141$ (a) as amended $\S 36,62$ 'STAT. 99 r-992 (1948).

${ }^{10}$ INT. REv. CODE of 1954, § 7482(a).

${ }^{30}$ Review of civil actions tried without a jury in the district courts is governed by FED. R. CIV. P. 52(a), which says that findings of fact may be set aside only if they are clearly erroneous but does not impose any limitation on the review of conclusions of law.

${ }^{22}$ See note 9 supra. 
struction of the tax laws. Reasonable resolution of this conceptual conflict impels the conclusion that Congress, to further a desired uniformity, established the Tax Court to aid in the administration of the growingly complex tax laws, ${ }^{22}$ but it expressly rejected Tax Court autonomy in this area by explicitly reserving to the circuit courts the power of review. ${ }^{23}$

Apart from probable congressional intent, which is often difficult precisely to ascertain ${ }^{24}$ this conclusion has much practically to recommend it. If the Tax Court were free to disregard the precedent of its reviewing body, not only would the adversely affected taxpayer be prejudiced to the extent of the time, money, and effort that he would be required to expend to effect an appeal, but the circuit court would be additionally burdened by consideration of matters it had previously settled, and the Tax Court itself would become merely a procedural step in the course of an adjudication. Consequently, if the taxpayer could afford it, he would be well advised to stay out of the Tax Court completely by paying the Commissioner the asserted deficiency and seeking recovery in the district court, ${ }^{25}$ which unequivocally acknowledges the authority of the circuit. This practice, if it became widespread, could not but detract from the prestige of the Tax Court, enlarge the case load of the other federal courts, and place a premium on financial ability to pay a deficiency assessment and to withstand protracted subsequent litigation.

Moreover, the countervailing policy arguments ${ }^{28}$ that are often ad-

${ }^{22}$ The Board of Tax Appeals was created as a judicial agency separate from the Bureau of Internal Revenue to help alleviate the great backlog of tax cases which piled up subsequent to the First World War. 67 Conc. REC. 370 (1925).

${ }^{28}$ Congress reserved the power when they amended the statute to do away with the Dobson rule.

${ }^{24}$ It does not appear from the legislative history that Congress ever envisoned the possibility of the event of the conflict which has arisen between the Tax Court and the courts of appeals.

${ }^{25}$ The district courts have jurisdiction concurrent with that of the Court of Claims to entertain suits against the United States in which the plaintiff is seeking to recover an overpayment of taxes. 28 U.S.C. $\S 1346(\mathrm{a})(\mathrm{I})(1952)$. At times it is beneficial to the taxpayer to overpay his taxes, if he can afford to do it without breaking up his financial holdings, because he receives $6 \%$ interest from the Government on the amount he recovers. INT. REV. CODE of $1954, \S 6611 ; 28$ U.S.C. 2411 (a) (1952).

${ }^{20}$ Perhaps the policy argument which the Tax Court feels is the most cogent, is that it, by remaining firm until a majority of the circuits have spoken or the Supreme Court has decided the matter, will lend more of a semblance of order or uniformity to the chaotic conditions caused by one court being reviewed by eleven, than it would if it went off into the many different directions taken by the courts of appeals. Although 
vanced tend to lose force when carefully analyzed. Thus, although a holding by the Tax Court inconsistent with its other holdings on the issue may depart considerably from the ideal, it would seem to be far preferable to a holding inconsistent with the holdings of the circuit court to which it will be appealed, at great inconvenience to the taxpayer, and by which it will be reversed. ${ }^{27}$ Nor should the likelihood of appeal in a particular case affect the court's determination in any way, since this would constitute the grossest discrimination against the litigant who could not afford to pursue his cause further.

The problems introduced by the uncertainty concerning the circuit court to which appeal will lie, too, are not as weighty as they would at first appear to be. The taxpayer has the right to appeal only to the court of the circuit in which he resides; $;^{28}$ and only if the Government agrees may he remove to another circuit. ${ }^{28}$ Thus, if the taxpayer's circuit has previously ruled on the issue in his favor, there is no question as to the court to which he would take his appeal. Likewise, if the taxpayer's circuit had previously. ruled on the issue adversely to his interests, the Commissioner, if need be, would take his appeal to this court.

This conflict between the Tax Court and the circuit courts of appeals involves more than a mere dispute among forums as to proper statutory constructions. It exposes a jurisprudentially unhealthy situation in which the law is unevenly enforced and in which there is no finality until the Supreme Court speaks. ${ }^{30}$ The resultant atmosphere of unfairness

there is some merit in this position, it still disregards the taxpayer who is forced into the appellate court.

${ }^{37}$ Even when the Tax Court is faced with a problem such as the one posed in note 8 , suppra, there is really no reason why the Tax Court could not adjudicate the rights of each stockholder separately according to the precedent of his circuit. Although it might seem strange for a court to decide the same issue in the same case differently for the various litigants, it would be preferable to forcing some of the litigants into the circuit courts for a remedy which is going to be theirs for the asking.

${ }^{28}$ A Tax Court decision may be reviewed by the court of appeals of the circuit in which the disputed return was filed. INT. REv. CoDE of 1954, § 7482(b)(1).

${ }^{30}$ Any court of appeals may review a decision of the Tax Court if the petitioner and the Government stipulate in writing to take it there. INT. REv. CoDE of 1954, $\S 7482(\mathrm{~b})(2)$.

${ }_{80}$ The majority of the tax cases reaching the Supreme Court receive review by that high tribunal because they involve alleged conflicts within the circuits. Griswold, $o p$. cit. supra note 9, at $1159-116_{3}$, cites many examples of instances where it has taken from seven to ten years for a conflict within the circuits to be resolved by the Supreme Court. But Remlin, A Time Study of Certain Tax Controversies, 16 Geo. Wash. I. REv. 238 (1948), says that as a rule the cases involving conflicts move faster through 
and uncertainty affects the rights of all taxpayers, whether or not they resort to the courts. ${ }^{31}$ Many commentators, ${ }^{32}$ therefore, have suggested that some relief might be afforded by the creation of a Court of Tax Appeals, which would hear all appeals in civil tax cases, and whose decisions would be reviewable only by the Supreme Court. This judicial innovation would relieve the circuit courts of appeals of the burden of adjudicating tax questions, ${ }^{33}$ and would destroy the pernicious "inverted triangle $\mathrm{e}^{34}$ by consolidating all tax appeals in a single forum. Ultimately, it offers the only really satisfactory solution to the problem presented by the instant cases.

litigation than the cases which do not, and the cases cited by Dean Griswold are a "few bad examples."

${ }^{31}$ While a conflict exists within the circuits, the Commissioner will usually refuse to acquiesce in decisions which are not in favor of the Government. This makes it hard on the taxpayers who do not or can not litigate their cases. On the other hand, the Commissioner is more likely to compromise, if there is a conflict in the circuits. Griswold, op. cit. supra note 9. Generally both the taxpayer and the Commissioner only want a rule, and in many cases one would be as good as another. But when a conflict develops within the circuits, they are without a rule, and they are forced to struggle along the best they can until the Supreme Court speaks. See Surrey, Some Suggested Topics in the Field of Tax Administration, 25 WASH. U.L.Q. 399 (1940).

${ }^{82}$ One of the earliest exponents of a revision along these lines was Traynor, Administrative and Judicial Procedure for Federal Income, Estate, and Gift TaxesA Critiscism and a Proposal, 38 Colum. L. Rev. 1393 (1938). This article served to stir up quite a bit of interest in the problem. See SuRREY, The Traynor Plon-What Is It, I 7 Taxes 393 (1939); Prettyman, Comment on the Traynor Plan for a Revision of Federal Tax Procedure, 27 Geo. L.J. 1038 (1939). See also Traynor and Surrey, New Roads Toward the Settlement of Federal Income, Estate, and Gift Tax Controoersies, 7 LaW \& Contemp. Prob. 336 (1940). Perhaps the leading article dealing with this topic is by Griswold, op. cit. supra note 9. But see, Miller, The Court of Last Resort in Tax Cases: $A$ Specialized Court of Tax Appeals, 40 A.B.A.J. $56_{3}$ (1954). In this article the author objects to the creation of a single appellate court for tax cases on several grounds including the alleged evil of having judges who are specialists. This argument is well answered by a court of appeals judge. Pope, $A$ Court of Tax Appeals: A Call for Re-examination, 39 A.B.A.J. 275 (1953).

${ }^{38}$ It is well known that the judges of the courts of appeals would be much happier if they did not have to deal with the highly technical tax cases. Pope, of. cit. supra note 36 .

"The term "inverted triangle" which was used by the court in the Lawrence case is often used to describe the type of review that the Tax Court is subject to, i.e. one lower court being reviewed by several higher courts instead of the usual method of one higher court reviewing the decisions of several lower courts. 